\title{
Correction to: Community participation and private sector engagement are fundamental to achieving universal health coverage and health security in Africa: reflections from the second Africa health forum
}

Olushayo Olu*, Pamela Drameh-Avognon², Emil Asamoah-Odei ${ }^{3}$, Francis Kasolo², Tomas Valdez ${ }^{4}$, Grace Kabaniha², Humphrey Karamagi ${ }^{2}$, Suvajee Good ${ }^{2}$, Helena O'Malley ${ }^{2}$, Zabulon Yoti ${ }^{2}$, Nirina Razakazoa ${ }^{2}$, Etienne Minkoulou ${ }^{2}$, Jean-Marie Dangou ${ }^{2}$, Symplice Mbola Mbassi ${ }^{2}$, Mariano Salazar Castellon ${ }^{4}$, Joseph Cabore ${ }^{2}$ and Matshidiso Moeti ${ }^{2}$

Correction to: BMC Proc (2019) 13:7

https://doi.org/10.1186/s12919-019-0170-0

From Second WHO Africa Health Forum

Praia, Cabo Verde. 26-28 March 2019

Following publication of the original article [1], the authors reported the following author name error is the article:

Incorrect: Thomas Valdez

Correct: Tomas Valdez

\begin{abstract}
Author details
'WHO Country Office, Juba, Republic of South Sudan. ${ }^{2}$ WHO Regional Office for Africa, Brazzaville, Republic of the Congo. ${ }^{3}$ Consultant, Regional Director's Office, WHO Regional Office for Africa, Brazzaville, Republic of the Congo.

${ }^{4}$ WHO Country Office, Praia, Cabo Verde.
\end{abstract}

Published online: 02 December 2019

\section{Reference}

1. Olu O, et al. Community participation and private sector engagement are fundamental to achieving universal health coverage and health security in Africa: reflections from the second Africa health forum. BMC Proc. 2019; 13(Suppl 9):7. https://doi.org/10.1186/s12919-019-0170-0.

Full list of author information is available at the end of the article

(c) The Author(s). 2019 Open Access This article is distributed under the terms of the Creative Commons Attribution 4.0 International License (http://creativecommons.org/licenses/by/4.0/), which permits unrestricted use, distribution, and reproduction in any medium, provided you give appropriate credit to the original author(s) and the source, provide a link to the Creative Commons license, and indicate if changes were made. The Creative Commons Public Domain Dedication waiver (http://creativecommons.org/publicdomain/zero/1.0/) applies to the data made available in this article, unless otherwise stated. 